\title{
REVIEW
}

\section{RISK OF FALLING IN PEDIATRIC NURSING}

\author{
Jana Chromá \\ Department of Paediatrics, University Hospital Ostrava, Czech Republic
}

Received April 11, 2016; Accepted July 8, 2016. Copyright: This is an open access article distributed under the terms of the Creative Commons Attribution International License (CC BY). http://creativecommons.org/licenses/by/4.0/

\begin{abstract}
Aim: The aim of this article is to describe, analyze and compare the assessment tools used to evaluate risk of falling in pediatric nursing. Design: Review - literature review. Methods: Electronic licensed and freely accessible databases (Bibliographia Medica Čechoslovaca, MEDLINE, Web of Science, PubMed a Scopus) were used to obtain data. Instruments for measuring risk of falling in languages other than Czech, Slovak or English, and scales unsuitable for measuring risk of falling in pediatric nursing were excluded from the analysis. Results: From analysis of the collected information, the most suitable tool for assessment of risk of falling in pediatric nursing seems to be the Humpty Dumpty measuring scale. Conclusion: At present there are many assessment tools that can be used to evaluate the risk of falling in pediatric nursing, but most are available in English. Czech pediatric nursing continues to lack measuring tools with verified psychometric properties.
\end{abstract}

Keywords: risk of fall, assessment, pediatrics, child, nursing.

\section{Introduction}

Falls in pediatric nursing are considered the riskiest and most frequent emergency incident. From the second half of the nineties, in connection with the implementation of quality systems and continuous monitoring of the quality of nursing care, the principle of providing adequate safety has been enforced in the Czech health system.

The issue of falls is one of the most discussed areas with regard to the quality and safety of care, both in the context of outpatient care, and the care that health and social institutions provide to hospital inpatients (Svobodová, 2013).

In the literature there is no uniform definition of a fall that is accepted at a national or international level. However, for the evaluation and monitoring of falls it is important that every medical facility should define what a fall is (Joint Commission Resources, 2007). This definition can then be accepted by health professionals so that it can be correctly and effectively used in the reporting of an emergency incident. A fall can be understood as an incident resulting in the unforeseen repose of a person on the ground, floor, or area of lower elevation (Heslin et al., 2006).

Corresponding author: Jana Chromá, Department of Paediatrics, University Hospital Ostrava, 17. listopadu 1790, Ostrava-Poruba, Czech Republic; e-mail: janachroma@centrum.cz.
Another definition is given by Joint Commission Resources (2005), whereby a fall is defined as an unintended event in which a person finds themselves on the ground or on a lower surface (when the fall is the witnessed), or the notification of such an event (when the fall is unwitnessed). A fall is not caused by an intentional movement or other cause, such as stroke, fainting, or epileptic seizure. Patients fall to the floor unexpectedly. Topinková (2005) defines a fall as an unexpected and involuntary change in position whereby the body comes into direct contact with the floor. Falls are a common area of nursing responsibility. Injury can result both from human error or without fault on the part of medical staff. Medical institutions are accountable for both the injuries caused by unlawful procedures, usually resulting from negligence of employees, and for injuries caused by procedures wherein the health worker acted correctly (Act No. 65/1965 Coll., The Ministry of Health Decree no. 440/2001).

In the Czech Republic, the monitoring and prevention of falls is mostly the responsibility of the Czech Association of Nurses (ČAS). Falls are monitored both for individual hospitals and centrally, and are included in adverse event reports. Records of falls from individual hospitals are collected as part of the National System for reporting adverse events. In the years 2004-2010, healthcare professionals recorded, from a total of 5,775,758 hospitalized patients, $45,897(0.79 \%)$ falls, $17,407(38 \%)$ of which resulted 
in minor injuries, and 4296 (9.36\%) of which resulted in serious injuries. The total number of falls involving injuries reached a total of $47 \%$ (Svobodová, 2013). Between 2011 and 2012, healthcare professionals monitoring quality indicators recorded, from a total of 1,545,504 hospitalized patients, 16,218 falls (1\%); 4,800 (30\%) of which resulted in minor injuries, and 1,417 (9\%) of which resulted in serious injuries. The total number of falls resulting in injury amounted to $39.38 \%$ (2011) and $37.17 \%$ (2012) respectively (Svobodová, 2013). Results from 2011 and 2012 confirm that injury prevention is a serious issue, as injuries of this type are of a long-lasting character, are accompanied by reduced mobility in patients, and may lead to prolongation of hospitalization, rehabilitation, and other comorbidities (Oliver et al., 2004; Graf, 2011; Schaffer et al., 2012).

In nursing practice, it is necessary to identify patients at risk of falling and to implement effective programs aimed at preventing falls. Although validated assessment scales exist in professional literature for the assessment of risk of falling in the adult population (O'Connell, Meyer, 2002; Hendrich, 2007), they are not suitable for use on children (Child Health Corporation of America Falls Nursing Study Task Force, 2009). The Accreditation Commission of medical devices JCAHO (2007) has set national safety targets for the prevention of falls in hospitalized children. Its directive states that all hospitalized children are to be assessed for risk of falling (Copeland, 2007).

\section{Aim}

The aim of the review was to describe, analyze and compare the measurement tools used to assess the risk of falling in pediatric nursing.

Research question: Which scales evaluating the risk of falling can be used for children?

\section{Methods}

\section{Design}

Review - literature review.

\section{Eligibility criteria}

Selection criteria were chosen, based on the research question. The selection included studies documenting results in Czech, Slovak, and English, and the full text of articles published between 2000-2016. Studies documenting the risk of falling in adults in specializations other than clinical pediatrics were excluded.

\section{Sources}

Czech and foreign electronic databases were used to find relevant sources dealing with the specified issues (Bibliographia Medica Čechoslovaca, MEDLINE, Web of Science, PubMed a Scopus).

\section{Search}

The following key words were used to search the relevant sources: risk of falling - assessment pediatrics - child - nursing, combined with the Boolean operators AND and OR. For each database the same search criteria were observed.

\section{Study selection and data analyses}

Based on analysis of Czech and relevant foreign literature from a total of 82 searches, the review included 14 studies, identifying six measurement instruments dealing with the issue of fall risk assessment in children. The articles featuring measuring tools were further analyzed and compared. The selection process for the studies is shown in figure 1, and was in accordance with PRISMA recommendations.

\section{Results}

Currently, the literature refers to numerous studies on fall risk assessment, but very few focus on the issue of risk of falling in children. Most studies examine only the incidence of risk of falling in adults and seniors. Some of these tools have been validated for the adult population and have led to the creation of programs for the prevention of falls in adults (Coker, Oliver, 2002; Henrich et al., 2003; Milisen et al., 2007). Some authors question the validity, sensitivity and specificity of the available screening tools (O'Connell, Myers, 2002; Meyers, Nikoletta, 2003), and state that there is an opportunity to improve the assessment and management of fall risk factors, and to improve education in this area (Tinetto et al., 2006; Fortinsky et al., 2008). Attempts to modify the evaluation of many tools assessing the risk of falling in the adult population of pediatric patients have been disappointing (Razmus et al., 2006), for example, the attempt to modify a version of the Schmid Fall Risk Assessment Tool (Schmid, 1990) for the pediatric population. While this tool is reliable and valid for an adult population, unfortunately, for fall risk assessment in children it has been shown to be an unreliable predictor (Child Health Corporation of American Falls Nursing Study Task Force, 2009). In addition, other modified tools, namely the Morse Fall Scale and Hendrich II Fall Risk Model, exhibited poor reliability for evaluation of falls in the pediatric population (Razmus et al., 2006). Although falls are the most common cause of 


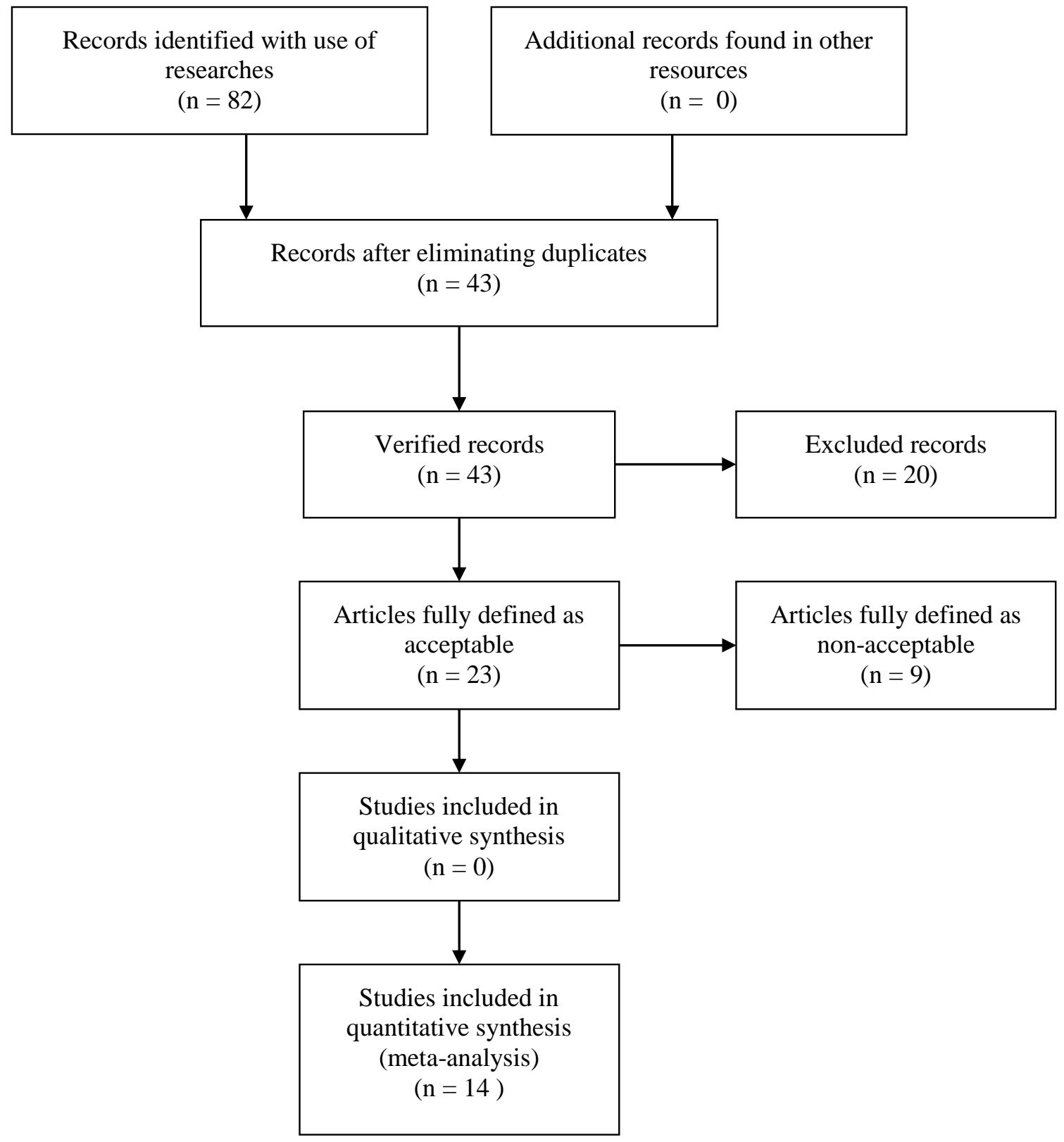

Figure 1 Flow chart - recommendation PRISMA

unintentional injury in children, published studies on the validation of assessment tools for risk of falling in pediatric nursing are very limited. Injuries to children are an important public health problem. There are a number of population analyses aimed at developing initiatives in the area of prevention (Pickett et al., 2003). The rate of injuries arising as a result of falls in the pediatric population is almost the same as in the adult population (Jamerson et al., 2014).
In Czech nursing practice we found no standardized tool for evaluating the risk of falling in the pediatric population. According to a study by Hlaváčková et al. (2012), the majority of Czech healthcare facilities (62.5\%) utilize proprietary, unverified research assessment tools. Most foreign tools for assessing the risk of falling ( $81 \%)$ in children have been developed internally within medical facilities, without 
verification of their psychometric properties (The Child Health Corporation of America Falls Nursing Study Task Force, 2009). The main reason for internally developed assessment tools are the limited opportunities to test their psychometric properties, sensitivity and specificity. Currently, instruments are beginning to appear in foreign literature with which these psychometric properties can be tested.
However, after analysis of the relevant literature, only six assessment tools dealing with the issue of fall risk assessment in children were recorded which met our selection criteria (Table 1). The assessment tools found were further analyzed and compared.

Table 1 Comparison of selected measuring instruments

\begin{tabular}{llcl}
\hline Scale & Author & Score risk of fall & Internal consistency \\
\hline Humpty Dumpty & Hill-Rodriguez et al. & 12 and more points & 0.64 \\
CHAMPS & Razmus, Wilson & more than 4 factors & 0.40 \\
CNMC & Children's National Medical Centre & 3 and more points & 0.69 \\
GRAF-PIF & Graf & 2 and more points & 0.77 \\
Cummings Tool & Communings & 8 and more points & 0.68 \\
PFRA & Ryan-Wenger et al. & & 0.60 \\
\hline
\end{tabular}

\section{Humpty Dumpty Falls Scale (HDFS C)}

The Humpty Dumpty Falls Scale is a special screening tool developed for the assessment of risk of falling in children. It contains seven dimensions that assess age, gender, diagnosis, cognitive disorders, environmental factors, response to surgery, sedation and anesthesia, and medications. Individual items are evaluated on a scale of one to four, whereby 12 points or more indicates high risk of falling. The tool is designed as a primary and secondary health care for children aged 3 to 18 years. Pilot testing ( $n=$ 38 children) of this instrument showed that there was an increased rate of injury in boys in comparison with girls. Low risk of falling was indicated by scores ranging from 7 to 11 points. Children with high risk of falling scored 12 points or more (Flavin et al., 2006). Internal consistency was 0.64 (Hill-Rodriguez et al. 2009).

\section{CHAMPS Tool}

CHAMPS Tool is a tool that has been developed for assessing the risk of falling in the pediatric population. The name of the Tool derives from the initials of the factors examined: Changes in mental status or dizziness, History of previous falls at home or in hospital, Age < three years old, Mobility problems in walking or moving, Parental or primary care giver Involvement in care, Safety actions in place. It was developed based on a paired controlled study in which the authors assessed 100 children whose falls were recorded (Kissinger, 2010). This instrument is currently under pilot testing. Instrument sensitivity is $84 \%$, and internal consistency was 0.40 (Copeland, 2007).

\section{GRAF PIF C}

The aim of the GRAF (C) PIF scale is to identify the risk of falling in children aged over 12 months (Nursing Practice Council, 2011). The scale assesses seven specific dimensions, namely: length of hospital stay, absence of intravenous entry or heparin plugs, indication of physical therapy or ergotherapy, anticonvulsant therapy, presence of orthopedic or musculoskeletal medical diagnosis, history of falls in the past month, and falls during current hospitalization (Graf, 2005). Internal consistency of the instrument was 0.84 . Sensitivity and specificity of the tool was identified as 0.75 and 0.76 (Graf, 2008).

\section{Cummings Pediatric Fall Assessment Tool}

Cummings Fall Pediatric Assessment Tool is a sixitem measuring tool that was developed by $\mathrm{R}$. Cummings at the Children's Hospital, Phoenix, Arizona. Testing was conducted in a controlled trial involving 78 children. The scale evaluates criteria such as: a history of falling, physical changes or impairments, functional status of the child, how their room is equipped, impaired cognition, and psychological condition, and medication that can affect balance. Internal consistency of the instrument was 0.68 (Cummings, 2006).

\section{Children's National Medical Centre (CNMC)}

The Children's National Medical Center (CNMC, 2005) is a 12-item instrument for assessing pediatric risk of falling, which is commonly used within hospital organizations in accordance with the guidelines of the National Center for Nursing Quality (NCNQ), ANA (ANA, 1996). Harvey et al. (2010), 
who examined the five pediatric tools for assessing risk of falling, caution that this tool (CNMC) demonstrated the smallest statistical accuracy and was not suitable for assessing children at greatest risk of falling. This study also confirmed that the length of hospitalization and previous falls during a hospital stay contribute to a higher risk of falling in children. The risk of falling is nine times higher in pediatric patients with behavioral disorders, and four times higher in pediatric patients with hematological medical diagnoses. Internal consistency of the instrument was 0.69 .

\section{Pediatric Falls Risk Assessment Tool (PFRA)}

The Pediatric Falls Risk Assessment Tool is a tenitem instrument evaluating the risk of falling in children, developed to identify patients with low and high risk of falling. In aretrospective controlled study involving 326 subjects aged one to 24 years of age, a sensitivity of 0.95 was recorded. Internal consistency of the instrument was 0.60 . However, accuracy was unacceptably low due to $60 \%$ falsepositive, and $58.5 \%$ false-negative risk ratings (Rayen-Wenger et al., 2012). None of the tested scales were precise and accurate enough to determine the risk of falling in pediatric patients.

\section{Discussion}

The task of every healthcare facility management is to develop standards aimed at reducing risk of falling and providing a safe environment for hospitalized patients (Šenkárová, 2012). A risk factor of falling in children may be the very nature of their reaction to hospitalization, which is unique to each child (depending on age, preparation, and family support). Previous hospitalizations and the support of hospital staff also play a part. The new environment, separation, pain, and fear of invasive procedures often result in a frightened and unhappy child (Leifer, 2004). As reported by many authors (Wirrell, 2006; Hill-Rodriguez et al. 2009; Svobodová, 2013) the risk of falling in children is also affected by acute or chronic diseases. In a controlled study of 153 children, those evaluated by the Humpty Dumpty tool as being at risk of falling have twice the incidence of falls of children considered to be at low risk of falling (Hill-Rodriguez, 2009). The highest score on the Humpty Dumpty Falls Scale were recorded in children who had respiratory (15.16 mean score) and neurological (mean score 14.84) medical diagnoses (Hill-Rodriguez et al., 2009). In health facilities using this evaluation screening tool, incidence of falls is reported to have fallen by $28 \%$ (Wood et al., 2006). Buck et al. (2007) also reported a significant decline in falls in pediatric patients after the introduction of the Humpty Dumpty Falls Scale. Sensitivity of this measuring tool was 0.85 . However, specificity was only 0.24 (Hill-Rodriguez et al., 2009). The total percentage of patients correctly classified as being at risk of falling was $59.3 \%$. The specificity of the Humpty Dumpty Falls Scale is question for further research in pediatric nursing (Messmer, Williams, 2012; Pauley et al., 2012).

Graf et al. (2005) in a controlled study involving 200 pediatric patients, identified the most common causes of falls in the pediatric population: physical/physiological factors $(61 \%)$, random factors $(33 \%)$, and unanticipated physiological falls $(6 \%)$. Accidental falls in the pediatric population occurred twice as often as in adult patient populations. Such falls occurred even in the presence of parents $(57 \%)$. Accidental falls occurred more frequently in children under the age of ten than in adolescents, while adolescents had more physiological falls compared to younger age groups. Unexpected physical/physiological falls can be caused by conditions such as undiagnosed seizure disorders. Hill-Rodrigues et al. (2009), who evaluated the risk of falling in children according to the Humpty Dumpty Falls Scale, like Graf et al. (2005), connect respiratory and neurological medical diagnoses with increased incidence of falls in children. Patients with a diagnosis of epilepsy were evaluated most at risk of falling. Higher frequency of epileptic seizures and other comorbidities, or cognitive impairments increase the risk of injury to a child (Wirrell, 2006).

Prevention of falls in the pediatric population is made more difficult by the unpredictability of falls due to the growth and development of pediatric patients. More than half the children younger than 12 months who experience a fall suffer serious injury as a result (Pickett et al., 2003). Most frequently this involves injuries to the head and face (Flavin et al., 2006). Infants and toddlers suffer the highest rate of injury caused by falls (Dedoukou et al., 2004; Flavin et al., 2006; Monson et al., 2008). Many studies (Murray et al., 2000; Vilku et al., 2004; Britton, 2005; Safe Kids Worldwide, 2008) state that children younger than ten years of age have a higher risk of injury or death associated with falls due to their incomplete motor development, curiosity, and the carelessness of their parents. Most falls correlated with environmental conditions such as children's beds, playrooms, and neglectful parents who leave children unattended (Henrich et al., 2007). A study by Jamerson et al. (2014) indicates that the majority of hospitalized children (77\%) fall in the presence an adult. Another study has found that falls increase in autumn (82.8\%) (Razmus et al., 2006). These conclusions represent a special challenge to the pediatric population. In 
light of the fact that caregivers are present when most children fall, it is important to focus on preventive measures in this area. Better knowledge of the nature and prevalence of fall risk factors makes possible the identification of pediatric patients at high risk of falling, which is an important step in designing preventive measures for this group of patients. The findings of the study also confirm the effectiveness of prevention programs in reducing the risk of falling in children (Pillai et al., 2000; McClure et al., 2005; Fujita et al., 2013; Lee et al., 2013). Hendrych (2007) recommends the integration of programs for the prevention of injuries to children with respect to their developmental level.

\section{Conclusion}

A large number of expert studies evaluating the risk of falling were researched, but very few authors focus on the specific issue of the assessment of risk of falling in children. From analysis of the collected information, the most suitable measuring tool for the assessment of risk of falling in pediatric nursing would seem to be the Humpty Dumpty Falls Scale. Results of the analysis of individual studies suggest that this tool is effective in identifying high risk of falling in the pediatric population. It is currently considered one of the best tools for the assessment of risk of falling in children. Screening for risk of falling should be a standard part of nursing procedure, and every medical facility should produce a protocol allowing the assessment of risk of injury to patients as a result of falls.

\section{Limitation of the study}

Only publications in Czech, Slovak and English, in full text, and available in electronic bibliographic databases were incorporated into this study.

\section{Ethical aspects and conflict of interest}

All bibliographical sources used have been cited. The author declares that the present study involves no conflicts of interest.

\section{References}

Britton JW. Kids can't fly: preventing fall injuries in children. Official Publication of the State Medical Society of Wisconsin. 2005;104(1):33-36.

Coker E, Oliver D. Evaluation of the STRATIFY falls prediction tool on a geriatric unit. Outcomes Management. 2003;7(1):8-14.

Copeland P. Patient falls conference: translating research into practice. [online]. [cited 2016 Mar 5]. Available from: http://scribd.com/doc/2322577/PSC-Newsletter-2007-summer Cummings R. Creating a Pediatric Fall Assessment Tool. Cummings pediatric fall assessment scale unpublished scale
C. 2006. [online]. Phoenix Children's Hospital, Phoenix, AZ [cited 2016 Mar 5]. Available from: https://stti.confex.com/stti/congrs06/techprogram/paper_3095 1.htm

Česko. Zákon č. 65 ze dne 16. června 1965 zákoník páce In. Sbírka zákonů České republiky. 1965, částka 172-186. Available from: http://www.mpsv.cz/ppropo.php?ID=z65_1965o (in Czech) Česko. Vyhláška MZČR č. 440 ze dne 31. listopadu 2001 o odškodnění bolesti a ztížení společenského uplatnění. In. Sbírka zákonů České republiky 2001. Available from: http://www.mpsv.cz/ppropo.php?ID=v440_2001 (in Czech) Dedoukou X, Spyridopoulos T, Kedikoglou S, Alexe DM, Dessypris N, Petridou E. Incidence and risk factors of fall injuries among infants: a study in Greece. Archive of Pediatric Adolescent Medicine. 2004;158(10):1002-1006.

Flavin MP, Dostaler SM, Simpson K, Brison RJ, Pickett W. Stages of development and injury patterns in the early years: a population-based analysis. BMC Public Health. 2006;6:187. Fortinsky RH, Baker D, Gottschalk M, King M, Trella P, Tinetti ME. Extent of implementation of evidence-based fall prevention practices for older patients in home health care. Journal of the American Geriatrics Society. 2008;56(4):737743.

Fujita Y, Fujita M, Fujiwara C. Pediatric falls: effect of prevention measures and characteristics of pediatric wards. Japan Journal of Nursing Science. 2013;10(2):223-231.

Graf ER. Pediatric hospital falls: development of a predictor model to guide pediatric clinical practice. Honor Society of Nursing. 2005. Available from: http://www.nursinglibrary.org/vhl/handle/10755/147928

Graf ER. Pediatric fall risk assessment classification: two hallmarks for a successful inpatient fall prevention program. Journal for the Society Pediatric Nurses. 2008;17(2):3-5.

Graf ER. Magnet children's hospitals: leading knowledge development and quality standards for inpatient pediatric fall prevention programs. Journal of Pediatric Nursing. 2011;26(2):122-127.

Harvey K, Kramlich D, Chapman J, Parker J, Blades E. Exploring and evaluating five pediatric falls assessment instruments and injury risk indicators: an ambispective study in a tertiary care setting. Journal of Nursing Management. 2010;18(5):531-541.

Hendrich AL, Bender PS, Nyhuis A. Validation of the Hendrich II Fall Risk Model: a large concurrent case/control study of hospitalized patients. Applied Nursing Research. 2003;16(1):9-21.

Hendrich AL. How to try this: predicting patient falls. Using the Hendrich II Fall Risk Model in clinical practice. American Journal of Nursing. 2007;107(11):50-58.

Hill-Rodriguez D, Messmer PR, Williams PD, Zeller RA, Williams AR, Wood M, Henry M. The Dumpty dumpty Falls Scale: a case-control study. Journal for Specialist in Pediatric Nursing. 2009;14(1):22-32.

Hlaváčková E, Klementová M, Macurová S. Jak je sledováno riziko pádů u dětí v českých zdravotnických zařízeních. Pediatrie pro praxi. 2012;13(6):412-414. (in Czech)

Child Health Corporation of America Nursing Falls Study Task Force. Pediatric falls: state of the science. Pediatric Nursing. 2009;35(4):227-231.

Jamerson P, Graf E, Messmer PR, Fields HW, Barton S, Berger A, Daraiseh NM, Fix M, Huth M, Latta L, Smith AB, Lunbeck M. Inpatient falls in freestanding children's hospitals. Pediatric Nursing. 2014;40(3):127-135. 
Joint Commission Resources. Reducing the risk of falls in your health organisation. 1th ed. USA: JCR; 2005.

Joint Commission Resources. Staff education tools for the national patient safety goals. 1th ed. USA: JRC; 2007.

Lee YL, Yip WK, Goh BW, Chiam EP, Ng HP. Fall prevention among children in the presence of caregivers in a paediatric ward: a best practice implementation. International Journal of Evidence-Based Healthcare. 2013;11(1):33-38.

Mcclure R, Nixon J, Spinks A, Turner C. Community-based programmes to prevent falls in children: a systematic review. Journal of Paediatrics and Child Health . 2005;41(9-10):465470.

Messmer PR, Williams AR. Protecting children by preventing falls. American Nurse Today. 2012;7(6).

Monson SA, Henry E, Lambert DK, Schmutz N, Christensen RD. In-hospital falls of newborn infants: data from a multihospital health care system. Pediatrics. 2008;122(2):e277-280.

Milisen K, Staelens N, Schwendimann R, De Paepe L, Verhaeghe J, Braes T, Boonen S, Pelemans W, Kressig RW, Dejaeger E. Fall prediction in inpatients by bedside nurses using the St. Thomas's Risk Assessment Tool in Falling Elderly Inpatients (STRATIFY) instrument: a multicenter study. Journal of the American Geriatrics Society. 2007;55(5):725-733.

Murray JA, Chen D, Velmahos GC, Alo K, Belzberg H, Asensio JA, Demetriades D, Berne TV. Pediatric falls: is height a predictor of injury and outcome? The American Surgeon. 2000;66(9):863-865.

Myers H, Nikoletti S. Fall risk assessment: a prospective investigation of nurses' clinical judgement and risk assessment tools in predicting patient falls. International Journal of Nursing Practice. 2003;9(3):158-165.

O'connell B, Myers H. The sensitivity and specificity of the Morse Fall Scale in an acute care setting. Journal of Clinical Nursing. 2002;11(1):134-136.

Pauley BJ, Houston LS, Cheng D, Johnston DM. Clinical relevance of the Humpty Dumpty Falls Scale in a pediatric specialty hospital. Pediatric Nursing. 2014;40(3):137-142.

Pickett W, Streight S, Simpson K, Brison RJ. Injuries experienced by infant children: a population-based epidemiological analysis. Pediatrics. 2003;111(4 Pt 1):e365370.

Pillai SB, Bethel CA, Besner GE, Caniano DA, Cooney DR. Fall injuries in the pediatric population: safer and most cost effective management. Journal of Trauma. 2000;48(6):10481051.
Razmus I, Wilson D, Smith R, Newman E. Falls in hospitalized children. Pediatric Nursing. 2006;32(6):568572.

Ryan-Wenger NA, Kimchi-Woods J, Erbaugh MA, LaFollette L, Lathrop J. Challenges and conundrums in the validation of Pediatric Fall Risk Assessment tools. Pediatric Nursing. 2012;38(3):159-167.

Safe Kids Worldwide. Facts about childhood falls. Retrieved March 12, 2008 [cited 2016 Mar 5]. Available from: http://www.safekidssonomacounty.org/pdf/fact_sheets/falls_f acts.pdf

Schaffer PL, Daraiseh NM, Daum L, Mendez E, Lin L, Huth MM. Pediatric inpatient falls and injuries: a descriptive analysis of risk factors. Journal for Specialists in Pediatric Nursing. 2012;17(1):10-18.

Schmid NA. 1989 Federal Nursing Service Award Winner. Reducing patient falls: a research based comprehensive fall prevention program. Military Medicine. 1990;155(5):202207.

Svobodová D. Sledování pádů u hospitalizovaných pacienti̊ $v$ letech 2011-2012. Česká Asociace Sester; 2013 [cited 2016 Mar 5]. Available from: http://www.cnna.cz/docs/tiskoviny/zaverecna_zprava_2011_2 012-91b6f.pdf (in Czech)

Šenkárová Z. Management pádů v ošetřovatelství. Sestra. 2012;22(9):36-37. (in Czech)

Škrla P, Škrlová M. Řizení rizik ve zdravotnických zařizeních. 1. vyd. Praha: Grada Publishing, a.s.; 2008. (in Czech)

Tinetti ME, Gordon C, Sogolow E, Lapin P, Bradley EH. Fall-risk evaluation and management: challenges in adopting geriatric care practices. The Gerontologist. 2006;46(6):717725.

Topinková E. Geriatrie pro praxi. 1.vyd. Praha: Galén, 2005. (in Czech)

Vilke GM, Stepanski BM, Ray LU, Lutz MW, Murrin PA, Chan TC. 9-1-1 responses for shopping cart and stroller injuries. Pediatric Emergency Care. 2004;20(10):660-663.

Wirrell EC. Epilepsy-related injuries. Epilepsia. 2006;47(Suppl 1):79-86.

Wood M, HIll-Rodriguez D, Messmer PR, PhD, Henry M, Salani D, Vazquez D, Soto ME, Minick Ch. Implementing a Humpty Dumpty Falls Scale for pediatric patients [online]. 2006. 17th International Nursing Research Congress Focusing on Evidence-Based Practice. [cited 2016 Mar 5]. Available from http://stti.confex.com/stti/congrs06/techprogram/paper_30374 .htm 